\title{
The Role of Online Teaching Among the Undergraduate Dental Students During the Current COVID-19 Pandemic in India: A Pilot Study
}

\author{
Sonu Acharya1@, Tharian B. Ematty², Sheetal Acharya ${ }^{3}$ (1)
}

\begin{abstract}
${ }^{1}$ Department of Pediatric and Preventive Dentistry, Institute of Dental Sciences, SOA (Deemed to be) University, Bhubaneswar, Odisha, India.

2Annoor Dental College \& Hospital, Muvattupuzha, Ernakulam Dist, Kerala, India.

${ }^{3}$ Department of Periodontology and Implant Dentistry, Institute of Dental Sciences, SOA (Deemed to be) University, Bhubaneswar, Odisha, India.
\end{abstract}

Correspondence: Sonu Acharya, Professor, Department of Pediatric and Preventive Dentistry Institute of Dental Sciences, SOA (Deemed to be) University, Bhubaneswar, Odisha, 751003, India. E-mail: sonu_ain@yahoo.com

Academic Editor: Alessandro Leite Cavalcanti

Received: 13 June 2020 / Review: 09 September 2020 / Accepted: 12 October 2020

\begin{abstract}
How to cite: Acharya S, Ematty TB, Acharya S. The role of online teaching among the undergraduate dental students during the current COVID-19 pandemic in India: a pilot study. Pesqui Bras Odontopediatria Clín Integr. 202 1; 21 :e0129. https://doi.org/10.1590/pboci.2021.045
\end{abstract}

\begin{abstract}
Objective: To assess the usefulness of online teaching for undergraduate students during this Corona pandemic, to point the drawbacks of online teaching, and to learn the areas of improvement in online teaching for the future. Material and Methods: A descriptive cross-sectional study on 130 students was done in Bhubaneswar, Odisha, India. The questionnaire consisted of two parts, personal details and specific information. The first part of the questionnaire consisted of questions related to age, gender, etc. The second part had questions pertaining to online teaching. Pearson's Chi-square test was applied and the level of significance was set at $5 \%$. Results: Most of the students $(83.3 \%)$ were in the view that classroom lectures are the best mean of imparting knowledge, which was significant $(\mathrm{p}<0.001)$. A significant number of students $(88.1 \%)$ agreed that online teaching is the best method of teaching apart from classroom teaching. Almost all the students (93\%) agreed significantly that online teaching is the best way to learn in this present pandemic scenario. Most students (59.6\%) agreed that connectivity/network issue is a major drawback in online teaching, which is again significant $(\mathrm{p}<0.001)$. Conclusion: Here in these testing times, the role of online teaching becomes important for medical/dental students, both undergraduates and postgraduates, to keep up with their studies.
\end{abstract}

Keywords: COVID-19; Teaching; Education, Distance; Education, Dental. 


\section{Introduction}

The basic concept of online learning is more than 150 years old. This type of learning was initiated through correspondence courses to facilitate learning beyond geographical and time barriers. Actual online learning began with the intranet in 1960, where linked computer terminals were used to provide academic material to students [1].

With the advent of Internet in 1994, digital literacy spread its wings in academics paving way for formal, accredited online courses and modules. The times have changed in the ways of imparting education in the past 20 years [2]. This can be attributed mostly to the growth and penetration of Internet services inside many households as well as the increase in usage of smartphones.

Medical/dental education also has adapted to these changes and have embraced these online learning platforms with grace. Online platforms are being used more often now by medical schools throughout the world and consist of adaptive tutorials, audiovisual aids, and virtual models. These educational methods possess several distinct advantages over traditional ways of classroom instructions, including the ways to update study material on time to ensure delivery of the latest evidence-based content to trainees [3].

Online teaching has been stated to be as effective as face-to-face teaching as it allows students to have greater flexibility and control over content and pace of studies. The advent of this new model of teaching has made many medical schools shift toward a "flipped classroom" model for learning [4]. This model is one of the methods of online teaching. In this, the students are told to study beforehand for the topic to be taught online, with the help of digital tools. This model of teaching is making medical educators to revamp their pedagogical toolbox.

There is, of course, a science to teaching: pedagogy. And in the medical education world, we are fortunate to have brilliant professors and researchers who - beyond their medical and scientific training - have taken it upon themselves to earn advanced degrees in education [5]. We have both types of teaching with their advantages and disadvantages. We have traditional lectures with good orators and great knowledge that can captivate the audience, e.g., students. Similarly, online teaching can be an enjoyable experience or become a dreary chore [6]. Indeed, online teaching is often a complement to instructor-led methods in a blended approach.

The role of online teaching can be well appreciated in times of difficult situations like war, natural calamities, strikes, pandemics. The world now is reeling under one such pandemic, the COVID-19 disease. Most of the countries are trying their best to fight this pandemic with all the means available. In these testing times, most of the places are under lockdown and it has become difficult for students, including medical/dental, to attend their schools. We did a short study to find out the role of online teaching for dental undergraduates in this pandemic situation.

Therefore, this study aims to assess the usefulness of online teaching for undergraduate students during this Corona pandemic, to point the drawbacks of online teaching, and to learn the areas of improvement in online teaching for future.

\section{Material and Methods}

Study Design and Sample

The cross-sectional study was conducted amongst the undergraduate dental students. This was an online questionnaire-based study. The questionnaire was sent to 130 dental undergraduate students, and 114 students completed the questionnaire. The respondents were undergraduate students in dental college. 


\section{Data Collection}

The students who were willing to participate only were requested to complete the questionnaire. The students were called and completely made to understand the purpose of the study. The questionnaire did not have any query on the name of the respondent, so that confidentiality is maintained. They were given reminders after two days through messages. In case of any difficulty, the respondents were told to contact any of the investigators. The questionnaire was validated by administering the questionnaire to 10 students initially. The questionnaire consisted of two parts, personal details and specific information. The first part of the questionnaire consisted of questions related to age, gender, etc. The second part had questions pertaining to online teaching.

\section{Data Analysis}

The respective data were collected, entered, and cleaned in Microsoft Excel before statistical analysis. The entire data were statistically analyzed using the Statistical Package for the Social Sciences (SPSS, version 17.0, Chicago, IL, USA) for Microsoft Windows. Pearson's Chi-square test was applied, and the level of significance was set at $5 \%$.

\section{Ethical Clearance}

The ethical clearance was taken by the institutional ethical review board (Protocol No. DMR/IMS$\mathrm{SH} / \mathrm{SOA} / 180631$ ) after sending them a mail for approval along with the study.

\section{Results}

The questionnaire was completed by 114 students. There were $32(28.1 \%)$ males and $82(79.1 \%)$ females who completed the questionnaire. The age varied from 20-25 years, with a mean age of 22.5 years.

Most of the students (83.3\%) were in the view that classroom lectures are the best mean of imparting knowledge, which was significant $(\mathrm{p}<0.001)$. A significant number of students $(88.1 \%)$ agreed that online teaching is the best method of teaching apart from classroom teaching. Almost all the students (93\%) agreed significantly that online teaching is the best way to learn in this present pandemic scenario. Most students $(59.6 \%)$ agreed that connectivity/network issue is a major drawback in online teaching, which is again significant $(\mathrm{p}<0.001)$. When the issue of taking exams online was raised, most $(61.4 \%)$ were against this as they wanted the old pattern of written exams since dental/medical studies are more subjective in nature. The students $(65.8 \%)$ also felt that online lectures could be attended from any place, which is convenient for them as in this pandemic situation, the country is under lockdown, and most students are in their homes. Many students $(42.1 \%)$ felt that online teaching needs improvement in being more interactive (Table 1 ). There was no difference in the distribution of opinion between the groups, male versus female.

Table 1. Questionnaire for assessing the role of online teaching.

\begin{tabular}{lrrr}
\hline \multicolumn{1}{c}{ Questions } & $\mathbf{N}$ & \% & p-value \\
\hline $\begin{array}{l}\text { Do you think real-time classroom teaching is the best way to impart } \\
\text { education? }\end{array}$ & & & \\
Yes & 95 & 83.3 & $<0.001$ \\
No & 19 & 16.7 &
\end{tabular}

Which method, according to you, is the most effective way to teach apart from classroom teaching?

Online Lectures 
$\begin{array}{lll}\text { Correspondence } & 6 & 5.3\end{array}$

$\begin{array}{lll}\text { Virtual Classroom } & 43 & 37.7\end{array}$

Video Conference $\quad 19 \quad 16.7$

Do you think online classes are of help during this COVID-19 pandemic?

Yes

$106 \quad 93.0<0.001$

No

What is the drawback of online lectures?

Clarity of Voice and Video

Connectivity Issue

21.9

$21.9<0.001$

Does not Feel Real

59.6

Difficulty in Clearing Doubts

$9 \quad 7.9$

$12 \quad 10.5$

Do you think, keeping in mind the present COVID-19 pandemic, exams

also should be held online?

$\begin{array}{lccc}\text { Yes } & 44 & 38.6 & 0.015 \\ \text { No } & 70 & 61.4 & <0.001 \\ \text { hat do you like the most about online classes? } & & & 9.6 \\ \text { Convenient Timings } & 11 & 65.8 & 2.6 \\ \text { Can be Attended from a Place of Convenience } & 75 & 3 & \\ \text { Ease of Understanding } & 25 & 21.9 \\ \text { No Fear of Missing the Class as it can be Recorded } & & \\ \text { hat improvement is required the most in online lectures? } & 36 & 31.6 & <0.001 \\ \text { Attentive Design } & 10 & 8.8 & 17.5 \\ \text { Lecture Content } & 20 & 42.1\end{array}$

\section{Discussion}

From the later half of the 20th century, the input of technology has made great changes to the traditional teaching methods. This culminated into a new science of learning / teaching culture with the Internet's advent. Online learning should engage the students with interactive sessions to become interesting [7]. At this juncture, when COVID-19 pandemic have brought the globe to a standstill, University Grants Commission of India instructed to their affiliate bodies that teaching should be continued in professional educational system through a digital platform. Although e-learning methodology was already in practice in many universities worldwide to most of the Indian medical and dental colleges, it was a new experience.

To assess the dental students response to Web Based Learning (W.B.L.), a pilot survey was done titled "Role of online teaching during the current Corona Pandemic". Out of the 114 responses to 10 survey questions, seven were considered for discussion. The majority of the students commented on the traditional classroom teaching as the best mode of imparting education (83.3\%). Adaptation to innovation depends on the people's behavioural attitude [8]. There will be a learning curve to a new system that will flatten with time and reinforcement of the results from the clinical outcome of education. Many previous scholars have reported that the outcome of web-based learning is comparable to traditional but never superior [9,10].

In the absence of a classroom, the most effective way of teaching, the result was split between online lectures and virtual classrooms while few suggested video conferencing and minimal opinion for correspondence courses. Health education to upcoming medical/dental students by correspondence learning is not recognized by any Indian universities. The limitation of virtual classrooms is the infrastructural facility limitation at Indian medical/dental schools on short notice. Moreover, the movement of faculty or student to a facilitating centre will be restricted in effective lockout situations. Students prefer a recordable lecture, which they are able to retrieve at their choice, which could be organized in online education [11]. 
Online learning was an important tool for learning in this pandemic to an overwhelming majority of students (93\%). Digital learning was a by-product of the advancement in science and technology, and its implementation into the academic curriculum was in a phased manner amongst the developing nations across the globe. In the COVID-19 scenario, there was an urgency for imparting e-learning and better acceptancy with present professional students as they are categorized to Millennials or Gen Nexters [12,13].

The drawback of online learning to most students was the practical problems of net connectivity and clarity of video and voice, which is interrelated, than to mode of teaching (81.5\%). The student satisfaction to elearning is directly dependent upon the downloading speed, infrastructural facilities of the locality or country and climatic conditions prevailing [9]. The least of drawback remark was that the class do not feel real. Rogers [14] explained that there will be late adapters whenever a new methodology is introduced to a curriculum.

In the Pandemic, whether exam should be conducted online, $61.29 \%$ of the respondents answered negatively. The existing exam pattern of dental academics is more subjective rather than objective and never digital. Changing to a new format is like fear of the unknown entity among the mindset of students. And probably they lack training in a new pattern. If the infrastructural facilities are inadequate, the result of the exam may affect them inadvertently.

The response to the best factor in online learning $(65.8 \%)$ was that the class can be attended from a place of convenience. This is one among the many advantages of e-learning noted by other pioneers $[15,16]$. The very intention of online teaching in the pandemic is to facilitate health education inspite of a national lockout and students being scattered. The improvement required in the present online lectures the opinion is mainly split between Interactive class and attentive design of the class (39.78\% v/s 32.26\%). The current data on e-learning globally accounts to blended learning in medical/dental schools [17]. The students are more used to the traditional way of classes and, when suddenly faced with e-learning in pandemic might be missing the face to face interaction with faculty. At the same time, faculty also have to improve e-teaching skills, set educational goals, and use of multimedia efficiently and effectively $[18,19]$.

\section{Conclusion}

Online teaching is a relatively new concept in medical field, which is fast expanding. It is important that postgraduate trainers, medical/dental schools and educators know the drawbacks and advantages of this form of teaching, and come out with solutions to facilitate this type of teaching, which becomes easier. This should be promoted amongst staff so that they are ready to teach in situations like the current COVID-19 pandemic. Online teaching is a huge help to students in crisis situations and so should be promoted more.

\section{Authors' Contributions}

$\begin{array}{lll}\text { SA } & \text { (D) https://orcid.org/O000-0003-1006-1993 } & \begin{array}{l}\text { Conceptualization, Methodology, Formal Analysis, Investigation, Curation, Writing - Original } \\ \text { Draft and Writing - Review and Editing. }\end{array} \\ \text { TBE } & \text { (D) } & \text { Formal Analysis, Investigation and Writing - Review and Editing. } \\ \text { SA } & \text { (D) https://orcid.org/Oooo-0002-4786-6237 } & \text { Formal Analysis, Investigation and Writing - Review and Editing. } \\ \text { All authors declare that they contributed to critical review of intellectual content and approval of the final version to be published. }\end{array}$

\section{Financial Support}

None.

\section{Conflict of Interest}

The authors declare no conflicts of interest. 


\section{Data Availability}

The data used to support the findings of this study can be made available upon request to the corresponding author.

\section{References}

[1] Tom T. The History of Online Education. 2017. Available from: https://www.petersons.com/blog/the-history-ofonline-education/. [Accessed on May 25, 2020].

[2] Schwartzstein RM, Roberts DH. Saying goodbye to lectures in medical school - paradigm shift or passing fad?. N Engl J Med 2017; 377(7):605-7. https://doi.org/10.1056/NEJMp1706474

[3] Warnecke E, Pearson S. Medical students' perceptions of using e-learning to enhance the acquisition of consulting skills. Australas Med J 201 1; 4(6):300-7. https://doi.org/10.4066/AMJ.2011.736

[4] Williams DE. The future of medical education: flipping the classroom and education technology. Ochsner J 2016; 16(1):14-5.

[5] Blissitt AM. Blended learning versus traditional lecture in introductory nursing pathophysiology courses. J Nurs Educ 2016; 55(4):227-30. https://doi.org/10.3928/01484834-20160316-09

[6] Sadeghi R, Sedaghat MM, Sha Ahmadi F. Comparison of the effect of lecture and blended teaching methods on students' learning and satisfaction. J Adv Med Educ Prof 2014; 2(4):146-50.

[7] Donkin R, Askew E. An evaluation of formative "in-class" versus "e-learning" activities to benefit student learning outcomes in biomedical sciences. J Biomed Education 2017; 2017(6):1-7. https://doi.org/10.1155/2017/9127978

[8] Cooper LF. Digital Technology: Impact and Opportunities in Dental Education. J Dent Edu 2019; 83(4):379-80. https://doi.org/10.21815/JDE.019.042

[9] Anderson T. How communities of inquiry drive teaching and learning in the digital age. Contact North. 2017. Available from: https://teachonline.ca/sites/default/files/pdf/e newsletters/how_communities_of_inquiry_drive_teaching_and_learning_in_the_digital.pdf. [Accessed on May 28, 2020].

[10] Lazarevic B, Bentz D. Student perception of stress in online and face-to-face learning: the exploration of stress determinants. Am J Distance Educ 2020; 1-14. https://doi.org/10.1080/08923647.2020.1748491

[11] Garrison DR, Anderson T, Archer W. The first decade of the community of inquiry framework: A retrospective. The Internet and Higher Education 2010; 13(1-2):5-9. https://doi.org/10.1016/j.iheduc.2009.10.003

[12] Howerton WB Jr, Enrique PRT, Ludlow JB, Tyndall DA. Interactive computer-assisted instruction vs. lecture format in dental education. J Dent Hyg 2004; 78(4):10.

[13] Oliver R. Exploring strategies for online teaching and learning. Dist Educ 1999; 20(2):240-54. https://doi.org/10.1080/0158791990200205

[14] Rogers EM. Diffusion of innovations. $5^{\text {th }}$. ed. New York: Free Press, 2003.

[15] Pahinis K, Stokes CW, Walsh TF, Cannavina G. Evaluating a blended learning course taught to different group of learners in a dental school. J Dent Educ 2007; 71(2):269-78. https://doi.org/10.1002/j.0022-0337.2007.71.2.tb04275.x

[16] Asiry MA. Dental students perception on online learning. Saudi Dent J 2017; 29(4):167-70. https://doi.org/10.1016/j.Sdentj2017.03.005

[17] Dziuban C, Graham CR, Moskal PD, Norberg A, Sicilia N. Blended learning: The new normal and emerging technologies. Int J Educ Technol Higher Educ 2018; 15:3. https://doi.org/10.1 186/s41239-017-0087-5

[18] Clunie L, Morris NP, Joynes VCT, Pickering JD. How comprehensive are research studies investigating the efficacy of technology-enhanced learning resources in anatomy education? A systematic review. Anat Sci Educ 2018; 11(3):303-19. https://doi.org/10.1002/ase.1762.

[19] McCann AL, Schneiderman ED, Hinton RJ. E-teaching and learning preferences of dental and dental hygiene students. J Dent Educ 2010; 74(1):65-78. https://doi.org/10.1002/j.0022-0337.2010.74.1.tb04856.x 